Article

\title{
Sol-Gel-Synthesis of Nanoscopic Complex Metal Fluorides
}

\author{
Alexander Rehmer ${ }^{1}$, Kerstin Scheurell ${ }^{1}$, Gudrun Scholz ${ }^{1}$ and Erhard Kemnitz ${ }^{1,2, *}$ \\ 1 Institut für Chemie, Humboldt-Universität zu Berlin, Brook-Taylor- Str. 2, D-12489 Berlin, Germany; \\ alex@daboiarussellii.de (A.R.); scheurek@rz.hu-berlin.de (K.S.); gudrun.scholz@chemie.hu-berlin.de (G.S.) \\ 2 Nanofluor GmbH, Rudower Chaussee 29, D-12489 Berlin, Germany \\ * Correspondence: erhard.kemnitz@chemie.hu-berlin.de; Tel.: +49-030-2093-7555
}

Received: 14 September 2017; Accepted: 24 October 2017; Published: 2 November 2017

\begin{abstract}
The fluorolytic sol-gel synthesis for binary metal fluorides $\left(\mathrm{AlF}_{3}, \mathrm{CaF}_{2}, \mathrm{MgF}_{2}\right)$ has been extended to ternary and quaternary alkaline earth metal fluorides $\left(\mathrm{CaAlF}_{5}, \mathrm{Ca}_{2} \mathrm{AlF}_{7}, \mathrm{LiMgAlF}_{6}\right)$. The formation and crystallization of nanoscopic ternary $\mathrm{CaAlF}_{5}$ and $\mathrm{Ca}_{2} \mathrm{AlF}_{7}$ sols in ethanol were studied by ${ }^{19} \mathrm{~F}$ liquid and solid state NMR (nuclear magnetic resonance) spectroscopy, as well as transmission electron microscopy (TEM). The crystalline phases of the annealed $\mathrm{CaAlF}_{5}, \mathrm{Ca}_{2} \mathrm{AlF}_{7}$, and $\mathrm{LiMgAlF}_{6}$ xerogels between 500 and $700{ }^{\circ} \mathrm{C}$ could be determined by $\mathrm{X}$-ray powder diffraction (XRD) and ${ }^{19} \mathrm{~F}$ solid state NMR spectroscopy. The thermal behavior of un-annealed nanoscopic ternary and quaternary metal fluoride xerogels was ascertained by thermal analysis (TG/DTA). The obtained crystalline phases of $\mathrm{CaAlF}_{5}$ and $\mathrm{Ca}_{2} \mathrm{AlF}_{7}$ derived from non-aqueous sol-gel process were compared to crystalline phases from the literature. The corresponding nanoscopic complex metal fluoride could provide a new approach in ceramic and luminescence applications.
\end{abstract}

Keywords: sol-gel; ternary metal fluorides; nano; ${ }^{19} \mathrm{~F}$ NMR; XRD

\section{Introduction}

The interest in complex metal fluorides $\left(\mathrm{KMgF}_{3}, \mathrm{CaAlF}_{5}, \mathrm{SrAlF}_{5}, \mathrm{LiCaAlF}_{6}, \mathrm{LiSrAlF}_{6}\right.$, and $\left.\mathrm{LiMgAlF}_{6}\right)$ is mainly caused by their thermoluminescent and chemical properties. These complex metal fluorides are often used as host materials for a wide range of applications in the optical luminescence field. They can be applied, for instance, as laser materials, thermoluminescent detectors, or phosphors for lamps and displays [1-7]. Furthermore, complex fluorides are appropriated in the ceramic field because of their good physical properties like high ionic strength, piezoelectric characteristics, and nonmagnetic insulator behavior [8]. Notably, the ternary metal fluorides $\left(\mathrm{CaAlF}_{5}, \mathrm{Ca}_{2} \mathrm{AlF}_{7}, \mathrm{SrAlF}_{5}\right.$, and $\left.\mathrm{Sr}_{2} \mathrm{AlF}_{7}\right)$ are used as fluoroaluminate substrates due to their very good chemical stability and remarkable optical properties [9-12]. $\mathrm{LiCaAlF}_{6}, \mathrm{LiMgAlF}_{6}$, and $\mathrm{LiSrAlF}_{6}$ are suitable hosts for solid-state lasers [2].

Generally, the synthesis of complex metal fluorides is predominantly based on solid state reactions at high temperatures and/or high pressures or by solvothermal synthesis [13]. The obtained particles usually exhibit diameters in the micrometer range. On the other hand, the fluorolytic sol-gel synthesis, discovered a few years ago, provides in general very convenient and easy access to nanoscopic fluorides [14]. Unfortunately, so far, this synthesis approach has not been deeply investigated for its applicability for the synthesis of complex fluorometallates. Therefore, it was the intention of this work to find out whether or not the applicability of the fluorolytic sol-gel approach can be extended to complex metal fluorides. As we will outline, this non-aqueous fluorolytic sol-gel approach seems to be a universal synthesis route.

Thus, we present an easy room temperature synthesis route to obtain nanoscopic complex metal fluorides which, as a result of thermal treatment between 500 and $700{ }^{\circ} \mathrm{C}$ for two minutes, transform into microcrystalline ternary and quaternary metal fluoride compounds. The synthesis of alkali and 
alkaline earth metal complex fluorides such as $\mathrm{KAlF}_{4}, \mathrm{Na}_{3} \mathrm{AlF}_{6}, \mathrm{BaAlF}_{5}, \mathrm{BaMgF}_{4}$, and $\mathrm{K}_{2} \mathrm{MgF}_{4}$ was successfully developed via the non-aqueous fluorolytic sol-gel route [15,16]. It has to be noted that the synthesis of ternary transition metal fluoride $\mathrm{Li}_{3} \mathrm{MF}_{6}(\mathrm{M}=$ transition metal $)$ has also been performed by the non-aqueous fluorolytic sol-gel route [16]. In this work, we adapted the metal chloride-based approach for the synthesis of transparent and stable $\mathrm{MgF}_{2}$ sols [17] on complex metal fluorides $\left(\mathrm{CaAlF}_{5}\right.$, $\mathrm{Ca}_{2} \mathrm{AlF}_{7}, \mathrm{LiMgAlF}_{6}$ ) because of their good solubility and the practical handling of $\mathrm{CaCl}_{2}$ and $\mathrm{MgCl}_{2}$ at ambient conditions. Thus, the chloride approach turned out to be a quite robust method compared to the alkoxide-based sol-gel route and enables transparent and long-time stable metal fluoride sols.

\section{Results and Discussion}

The fluorolytic sol-gel synthesis of binary metal fluorides $\left(\mathrm{HS}-\mathrm{AlF}_{3}, \mathrm{MgF}_{2}\right.$, and $\mathrm{CaF}_{2}$ ) derived from different metal precursors such as metal alkoxides, [18,19] metal acetates [20], and metal chlorides [21,22] allows access to monodisperse nanoscopic particles with a broad range of potential applications including optic, catalysis, and ceramic [23]. Notably, we succeeded in the synthesis of transparent and long-time stable $\mathrm{CaF}_{2}$ sols prepared from calcium ethoxide and calcium isopropoxide for the first time just by increasing the polarity of the solvent in the $\mathrm{CaF}_{2}$ system. We used ethylene glycol instead of methanol or ethanol as the solvent. Thus, the calcium alkoxides $\left(\mathrm{Ca}(\mathrm{OEt})_{2}\right.$ and $\left.\mathrm{Ca}\left(\mathrm{O}^{i} \mathrm{Pr}\right)_{2}\right)$ are soluble at room temperature [24]. We assume that the long-time sol stability of the $\mathrm{CaF}_{2}$ nanoparticles could be due to the higher viscosity and polarity of ethylene glycol compared to methanol and ethanol, respectively.

Due to the access of nanoscaled binary metal fluorides via the fluorolytic sol-gel route, we have adapted the synthesis principle for nanoscopic ternary and quaternary alkaline earth metal fluorides, e.g., by following the chloride approach as developed for $\mathrm{MgF}_{2}$ sols [17]. The general synthesis of complex metal fluorides via the chloride approach is represented by Equations (1)-(4).

Ternary metal fluorides

$$
\begin{gathered}
\mathrm{x} \mathrm{CaCl}_{2}+\mathrm{y} \mathrm{Al}\left(\mathrm{O}^{\mathrm{i}} \mathrm{Pr}\right)_{3} \stackrel{(\mathrm{x}+\mathrm{y}) \mathrm{HF}_{\mathrm{EtOH}}}{\rightarrow} \text { nano } \mathrm{Ca}_{\mathrm{x}} \mathrm{Al}_{\mathrm{y}} \mathrm{F}_{(\mathrm{x}+\mathrm{y})}+2 \mathrm{xHCl}+3 \mathrm{y}{ }^{\mathrm{i}} \mathrm{PrOH} \\
\mathrm{LiOMe}+\mathrm{MgCl}_{2} \stackrel{\mathrm{HF}_{\text {EЮH }}}{\rightarrow} \text { nano “ } \mathrm{LiMgF}_{3} \text { ” }+2 \mathrm{HCl}+\mathrm{MeOH}
\end{gathered}
$$

\section{Quaternary metal fluorides}

$$
\begin{aligned}
& \mathrm{LiOMe}+\mathrm{Al}\left(\mathrm{O}^{\mathrm{i}} \mathrm{Pr}\right)_{3}+\mathrm{MgCl}_{2} \stackrel{\mathrm{HF}_{\mathrm{EfOH}}}{\rightarrow} \text { nano } \mathrm{LiMgAlF}_{6}+2 \mathrm{HCl}+\mathrm{MeOH}+3^{\mathrm{i}} \mathrm{PrOH} \\
& \mathrm{Ba}(\mathrm{OH})_{2}+\mathrm{Al}\left(\mathrm{O}^{\mathrm{i}} \mathrm{Pr}\right)_{3}+\mathrm{CaCl}_{2} \stackrel{\mathrm{HF}_{\text {ЕОН }}}{\rightarrow} \text { nano } \mathrm{BaCaAlF}_{7}+2 \mathrm{HCl}+\mathrm{EtOH}+3^{\mathrm{i}} \mathrm{PrOH}
\end{aligned}
$$

By using $\mathrm{Al}\left(\mathrm{O}^{i} \mathrm{Pr}\right)_{3}, \mathrm{CaCl}_{2}$, and $\mathrm{EtOH}$, the formation of transparent ternary calcium fluoroaluminate sols like $\mathrm{CaAlF}_{5}$ and $\mathrm{Ca}_{2} \mathrm{AlF}_{7}$ is favored. Further complex metal fluorides such as $\mathrm{LiMgAlF}_{6}, \mathrm{BaCaAlF}_{7}$, and $\mathrm{LiMgF}_{3}$ were investigated. It turned out that a stoichiometric composition of $\mathrm{LiMgAlF}_{6}$ and $\mathrm{LiMgF}_{3}$ resulted in transparent sols (see Figure S1, Supplementary Material). Transparent sols of nanoscopic $\mathrm{BaCaAlF}_{7}$ were not obtained under all conditions tested. In the case of $\mathrm{LiMgF}_{3}$, there was no indication for its formation under either reaction conditions. Almost nanoscopic $\mathrm{MgF}_{2}$ particles, as well as a magnesium alkoxide fluoride species like $\mathrm{MgF}_{2-x} \mathrm{OR}(\mathrm{R}=\mathrm{H}, \mathrm{Et})$ [25], were identified by liquid ${ }^{19} \mathrm{~F}$ NMR spectroscopy of the sol and XRD of the dried xerogel (Figures S2 and S4, supplementary material), which is probably caused by a preferential oxygen donation. Interestingly, the XRD pattern of the annealed nominal $\mathrm{LiMgF}_{3}$ compound revealed unidentified reflections in addition to $\mathrm{LiF}$ and $\mathrm{MgF}_{2}$ (Figure S5, Supplementary Material). Furthermore, the determination of the particle size distribution of all complex metal fluorides by dynamic light scattering (DLS) failed. Although no turbidity of the corresponding sols was observed, there are either invisible agglomerates of primary nanoparticles disturbing the measurements or the very low refractive index of these compounds limits the application 
of DLS under these circumstances. Even the presence of non-spherical nanoparticles might cause the inappropriateness of DLS for particle size distribution.

\section{1. $\mathrm{CaAlF}_{5}$}

The $\mathrm{CaF}_{2}-\mathrm{AlF}_{3}$ binary system is well investigated [26,27]. The first study of $\mathrm{CaF}_{2}-\mathrm{AlF}_{3}$ was described by Fedotiev and Ylinskii [28]. A simple eutectic diagram with an invariant eutectic point at $820{ }^{\circ} \mathrm{C}$ and $37.5 \mathrm{~mol} \% \mathrm{AlF}_{3}$ was suggested. There are two compounds in the binary $\mathrm{CaF}_{2}-\mathrm{AlF}_{3}$ system; a dimorphic $\mathrm{CaAlF}_{5}$ which has a reversible $\alpha \leftrightarrow \beta$ transition around $740{ }^{\circ} \mathrm{C}$ and $\mathrm{Ca}_{2} \mathrm{AlF}_{7}$.

$\mathrm{CaAlF}_{5}$ was first identified by Holm by differential thermal analysis (DTA) experiments [29]. It melts incongruently at $873{ }^{\circ} \mathrm{C} \pm 3{ }^{\circ} \mathrm{C}$ to form $\mathrm{AlF}_{3}$ and an un-identified liquid phase. Powder diffraction measurements and ${ }^{19} \mathrm{~F}$ MAS NMR spectroscopy were performed to confirm the crystal structure of $\mathrm{CaAlF}_{5}$ [30-32] and $\mathrm{Ca}_{2} \mathrm{AlF}_{7}$ [32-35]. Both crystal structures correspond to those found in the naturally occurring phases in Jakobssonite [36] $\left(\mathrm{CaAlF}_{5}\right)$ and Carlhintzeite [37] $\left(\mathrm{Ca}_{2} \mathrm{AlF}_{7} \cdot \mathrm{H}_{2} \mathrm{O}\right)$, respectively. However, to the best of our knowledge, no synthetic phase of $\mathrm{CaAl}_{2} \mathrm{~F}_{8}$, which occurs in Prosopite $\left(\mathrm{CaAl}_{2}(\mathrm{~F}, \mathrm{OH})_{8}\right)$, has been reported so far.

In Figure 1, the ${ }^{19} \mathrm{~F}$ liquid NMR spectrum of $\mathrm{CaAlF}_{5}$ sol is shown. Due to the formation of nanoparticles in the sol, the line width of the NMR signals for $\mathrm{CaAlF}_{5}$ species is very broad. The crystal structure of $\alpha-\mathrm{CaAlF}_{5}$ reveals three ${ }^{19} \mathrm{~F}$ NMR peaks which correspond to three distinct fluorine sites with multiplicities of 2,2, and 1 . The fluorine sites in $\mathrm{CaAlF}_{5}$ are connected with one aluminum and two calcium Al-F-Ca(2), one aluminum and calcium Al-F-Ca, and between two aluminum and one calcium $\mathrm{Al}-\mathrm{F}-\mathrm{Al}\left(+\mathrm{Ca}\right.$ ), with chemical shifts relative to $\mathrm{CF}_{3} \mathrm{Cl}$ of $-146.2,-154.3$, and $-164 \mathrm{ppm}$, respectively $[32,35]$. Furthermore, the liquid NMR spectrum of the $\mathrm{CaAlF}_{5}$ sol shows two small signals (line width around $350 \mathrm{~Hz}$ ) at $-174 \mathrm{ppm}$ and $-179 \mathrm{ppm}$, which can probably be assigned to unreacted HF adsorbed at the particle surface in a mix of isopropanol and ethanol [21,22,38]. The presence of isopropanol in the $\mathrm{CaAlF}_{5}$ sol is probably caused by the reaction of $\mathrm{Al}\left(\mathrm{O}^{i} \mathrm{Pr}\right)_{3}$ with HF-solution. The broad main signals at about -146 and $-164 \mathrm{ppm}$ in the liquid NMR spectrum can be indicated as known species of $\mathrm{CaAlF}_{5}$. A ${ }^{19} \mathrm{~F}$ NMR signal for $\mathrm{CaF}_{2}(-108 \mathrm{ppm})$ in the spectrum could not be observed. The broad signal around $-190 \mathrm{ppm}$ is the known background from the fluorine NMR probe.

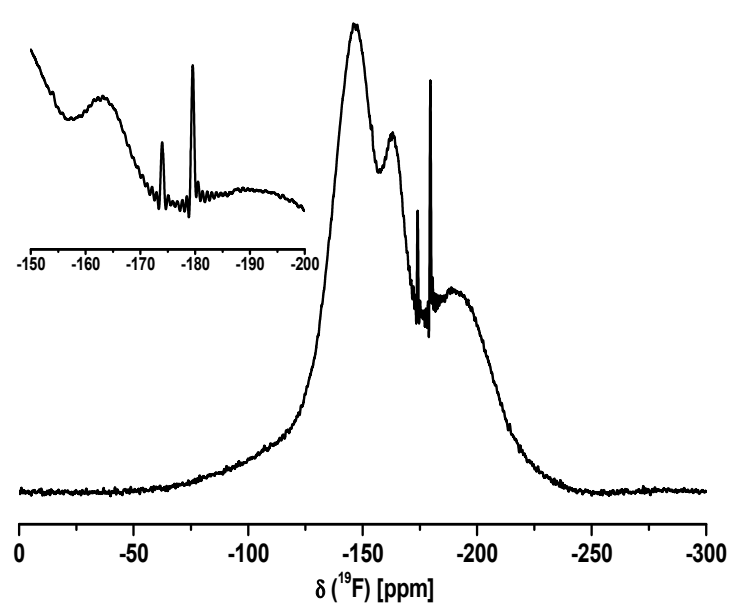

(a)

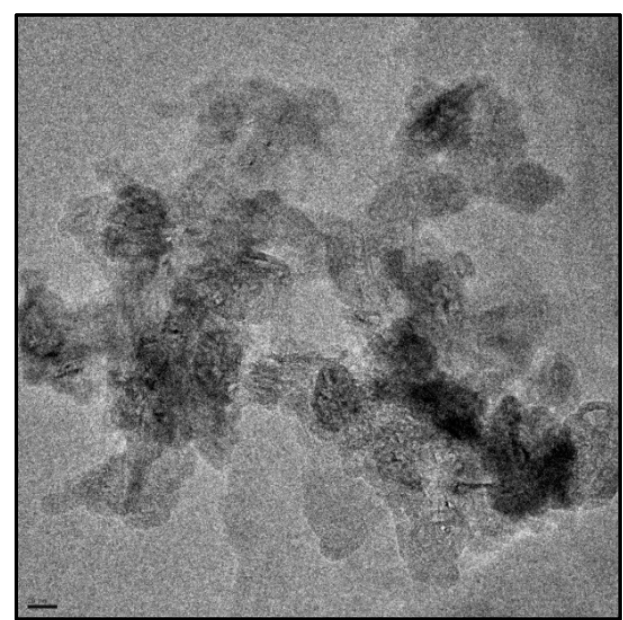

(b)

Figure 1. ${ }^{19} \mathrm{~F}$ liquid NMR spectrum (a) and TEM image $(\mathbf{b}) \mathrm{CaAlF}_{5}$ sol in EtOH (scale bar $=20 \mathrm{~nm}$ ).

Due to the problem of the particle size characterization by DLS, the particle size and shape were investigated by TEM. Figure $1 \mathrm{~b}$ shows a group of several agglomerated particles showing diameters above $20 \mathrm{~nm}$, but it seems that the particles exhibit a nearly spherical shape. After evaporation of the solvent from $\mathrm{CaAlF}_{5}$ sol, the $\mathrm{CaAlF}_{5}$ xerogel was characterized by XRD and ${ }^{19} \mathrm{~F}$ MAS NMR spectroscopy. Calcination below $500{ }^{\circ} \mathrm{C}$ revealed still X-ray amorphous samples. Samples calcined at 
$500{ }^{\circ} \mathrm{C}$ for $5 \mathrm{~h}$ gave reflections of $\mathrm{CaF}_{2}$ as indicated in the diffractogram (Figure 2). No X-ray patterns of $\mathrm{CaAlF}_{5}$ could be identified. Interestingly, if the xerogel was annealed at $700{ }^{\circ} \mathrm{C}$ for only a two minute calcination time in a closed crucible, the reflections of $\mathrm{CaAlF}_{5}$ can be observed (Figure 3). It is crucial to determine whether an open or closed crucible and whether a preheated or non-preheated oven is used. Probably, the calcination process of $\mathrm{CaAlF}_{5}$ results in a sublimation of $\mathrm{AlF}_{3}$. This could explain the formation of $\mathrm{CaF}_{2}$ in the $\mathrm{CaAlF}_{5}$ xerogel after calcination at $500{ }^{\circ} \mathrm{C}$ for $2 \mathrm{~h}$.

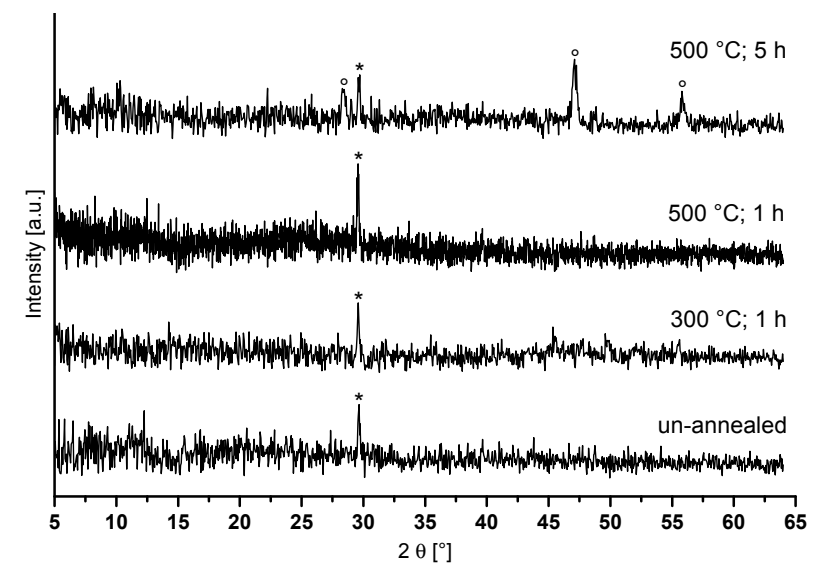

Figure 2. Powder diffractograms of $\mathrm{CaAlF}_{5}$ xerogel in a normal crucible at different thermal treatment in a non-preheating oven $\left({ }^{*}\right.$ sample holder, $\left.{ }^{\circ} \mathrm{CaF}_{2}\right)$.

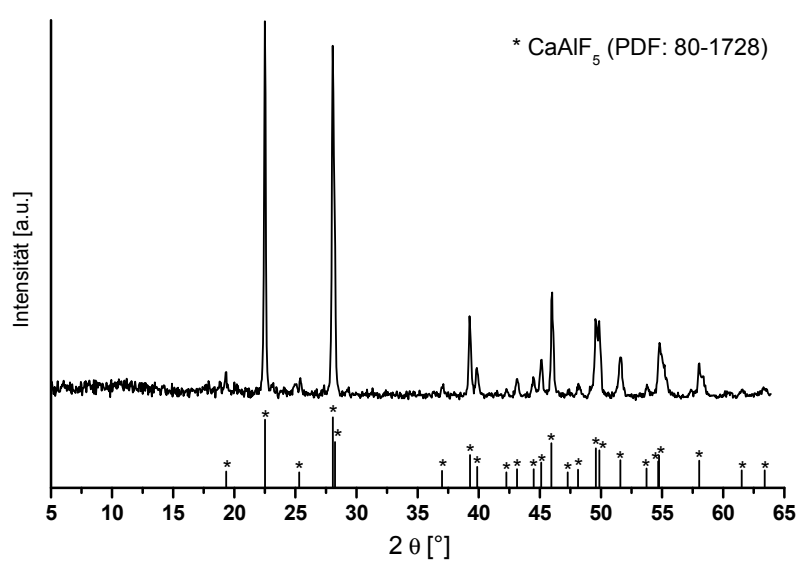

Figure 3. Comparison of powder $\mathrm{X}$-ray patterns of $\mathrm{CaAlF}_{5}$ xerogel in a closed crucible at $700{ }^{\circ} \mathrm{C}$ for a two minute calcination time in a preheated oven at $700{ }^{\circ} \mathrm{C}$ with crystalline $\mathrm{CaAlF}_{5}$ phase (PDF: 80-1728).

In Figure 4, the ${ }^{19} \mathrm{~F}$ MAS NMR spectra and the TG/DTA heating curves of $\mathrm{CaAlF}_{5}$ xerogel confirm the formation of crystalline $\mathrm{CaAlF}_{5}$. The spectrum of the un-annealed xerogel exhibits one broad signal around $-149 \mathrm{ppm}$ and two small signals ( $-128 \mathrm{ppm}$ and $-152 \mathrm{ppm})$. Both small signals can be indicated as $\mathrm{SiF}_{6}{ }^{2-}(-128 \mathrm{ppm})$ and $\mathrm{BF}_{4}{ }^{-}(-152 \mathrm{ppm})$ species, which result from the unreacted HF with the glass flask. It is obvious that the thermal treatment of the xerogel at $700{ }^{\circ} \mathrm{C}$ reveals three signals in the ${ }^{19} \mathrm{~F}$ NMR spectrum, which correspond to crystalline $\alpha-\mathrm{CaAlF}_{5}$ with a relative intensity of 45,36 , and 18 . In the literature, $\alpha-\mathrm{CaAlF}_{5}$ has three ${ }^{19} \mathrm{~F}$ signals with a relative intensity of 40,40 , and 20 , whereas $\beta-\mathrm{CaAlF}_{5}$ has four ${ }^{19} \mathrm{~F}$ signals with a relative intensity of $15,57,15$, and 13 [32]. Thus, we think that the annealed xerogel correlates more $\alpha-\mathrm{CaAlF}_{5}$ than $\beta-\mathrm{CaAlF}_{5}$ phase. Especially, the phase diagram of the $\mathrm{CaF}_{2}-\mathrm{AlF}_{3}$ binary system with $50 \mathrm{~mol} \% \mathrm{CaF}_{2}$ confirms the presence of $\alpha-\mathrm{CaAlF}_{5}$ until $743{ }^{\circ} \mathrm{C} \pm 3{ }^{\circ} \mathrm{C}$ [26]. Furthermore, the thermal behavior of the $\mathrm{CaAlF}_{5}$ xerogel was investigated by thermogravimetry and DTA. The DTA heating curve of the $\mathrm{CaAlF}_{5}$ xerogel shows several exothermic peaks below $600^{\circ} \mathrm{C}$ and a melting point at $894^{\circ} \mathrm{C}$. Craig and Brown found a melting point for $\beta-\mathrm{CaAlF} 5$ 
at $879{ }^{\circ} \mathrm{C}$ in the $\mathrm{CaF}_{2}-\mathrm{AlF}_{3}$ binary system [26]. Due to the synthesis in ethanol and the aluminum alkoxide precursor, the organic residue of ethanol in the xerogel is still present. Thus, the peak at $321{ }^{\circ} \mathrm{C}$ is probably the decomposition of the organic residue. At around $458{ }^{\circ} \mathrm{C}$, we assume that the polymorphic inversion of $\mathrm{AlF}_{3}$ occurs $\left(\approx 454{ }^{\circ} \mathrm{C}\right)$, which is noted by Holm [39].

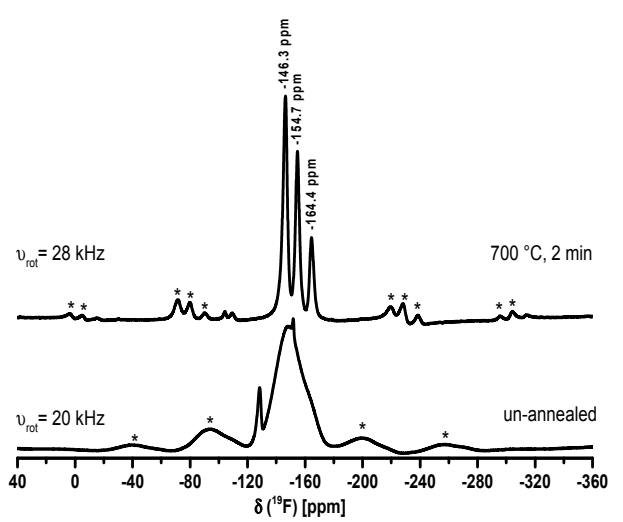

(a)

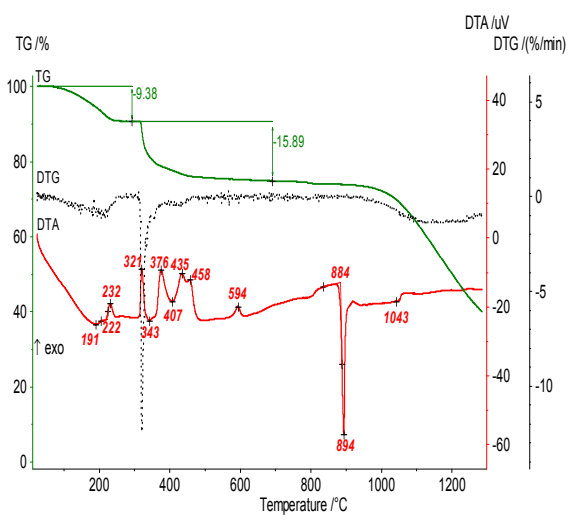

(b)

Figure 4. ${ }^{19} \mathrm{~F}$ MAS NMR spectra of un-annealed and annealed $\mathrm{CaAlF}_{5}$ xerogel at $700{ }^{\circ} \mathrm{C}$ for two minutes (a) and TG/DTA heating curves (b). The spinning sidebands in the MAS NMR spectrum are located under the ${ }^{*}$ symbols.

\section{2. $\mathrm{Ca}_{2} \mathrm{AlF}_{7}$}

In the $\mathrm{Ca}_{2} \mathrm{AlF}_{7}$ system, we only obtained a transparent and long-time stable sol by the addition of $5 \mathrm{~mol} \% \mathrm{TMOS}$ (tetramethyl orthosilicate). Apparently, the amount of $66 \mathrm{~mol} \% \mathrm{Cl}$ instead of $50 \mathrm{~mol} \% \mathrm{Cl}$ results in a faster agglomeration of the particles followed by sedimentation. According to pure $\mathrm{CaF}_{2}$ sols from $\mathrm{CaCl}_{2}$ in $\mathrm{EtOH}$, we observed the same effect of particle agglomeration. The addition of $5 \mathrm{~mol} \%$ TMOS to an opaque $\mathrm{CaF}_{2}$ sol that was formed after $\mathrm{HF}$ addition resulted in a transparent sol that was obtained within a few minutes [22]. Hence, the chloride amount in the calcium fluoroaluminate system is crucial to determing whether a transparent or turbid sol is formed. ${ }^{19} \mathrm{~F}$ liquid NMR spectrum and TEM images of $\mathrm{Ca}_{2} \mathrm{AlF}_{7}$ sol are shown in Figure 5.
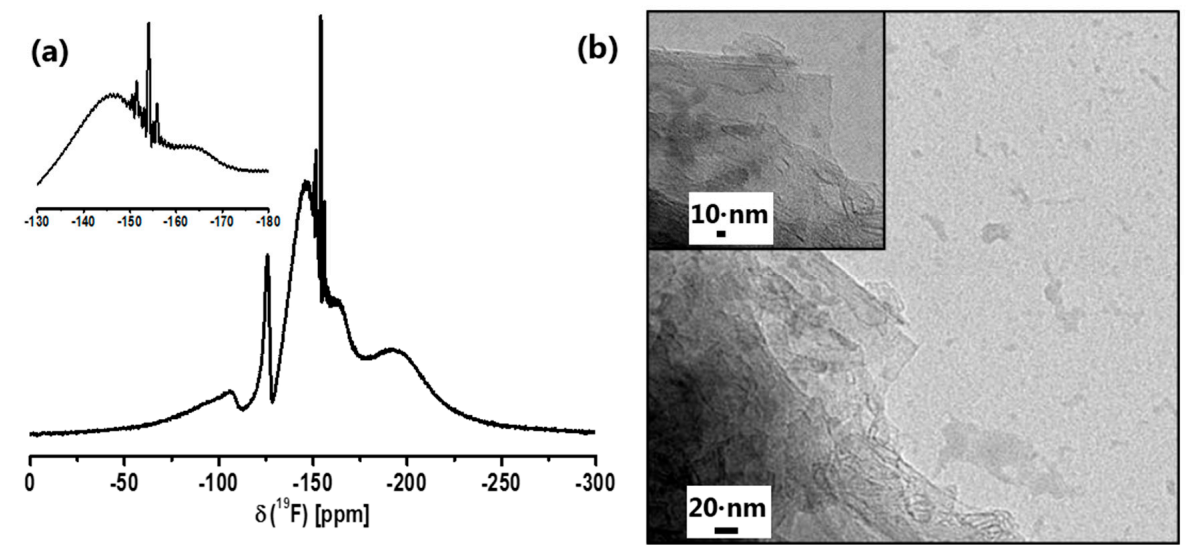

Figure 5. ${ }^{19} \mathrm{~F}$ liquid NMR spectrum (a) and TEM image (b) of $\mathrm{Ca}_{2} \mathrm{AlF}_{7}$ sol in EtOH.

In the ${ }^{19} \mathrm{~F}$ liquid NMR spectrum of the $\mathrm{Ca}_{2} \mathrm{AlF}_{7}$ sol, the corresponding broad signals at around $-146 \mathrm{ppm}$ and $-163 \mathrm{ppm}$ can be assigned to $\mathrm{Ca}_{2} \mathrm{AlF}_{7}$ and $\mathrm{CaAlF}_{5}$, respectively. Moreover, the signals at -106 and $-125 \mathrm{ppm}$ are characteristic for $\mathrm{CaF}_{2}$ and $\mathrm{SiF}_{6}{ }^{2-}$-species. The small signals between -150 and $-156 \mathrm{ppm}$ are related to alkoxyfluorosilanes $(\mathrm{RO})_{4-x}-\mathrm{SiF}_{x}(\mathrm{R}=\mathrm{Me}, \mathrm{Et})$. [40] The crystal structure of $\mathrm{Ca}_{2} \mathrm{AlF}_{7}$ has five distinct fluorine sites. One fluorine site is connected to three calcium 
$\mathrm{F}-\mathrm{Ca}(3)$ and four fluorine sites are connected to aluminum and calcium with varying numbers of calcium Al-F-Ca(n) [33]. The corresponding ${ }^{19} \mathrm{~F}$ MAS NMR spectrum of $\mathrm{Ca}_{2} \mathrm{AlF}_{7}$ reveals three signals with chemical shifts relative to $\mathrm{CF}_{3} \mathrm{Cl}$ of $-104.0,-146.7$, and $-152.2 \mathrm{ppm}$ [35].

The TEM image of the $\mathrm{Ca}_{2} \mathrm{AlF}_{7}$ sol represents small spherical-like particles. Remarkably, the agglomeration partially leads to an angular shape of bigger particles, which is shown in the insight of the TEM image.

The powder diffractogram of the annealed $\mathrm{Ca}_{2} \mathrm{AlF}_{7}$ xerogel shows reflections of $\mathrm{Ca}_{2} \mathrm{AlF}_{7}, \mathrm{CaAlF}_{5}$, and $\mathrm{CaClF}$ (Figure 6). The phase diagram of $\mathrm{CaF}_{2}-\mathrm{AlF}_{3}$ with a composition of $66 \mathrm{~mol} \% \mathrm{CaF}_{2}$ predicts $\mathrm{CaAlF}_{5}$ and $\mathrm{Ca}_{2} \mathrm{AlF}_{7}$. The formation of $\mathrm{CaClF}$ was already reported and discussed in the synthesis of $\mathrm{CaF}_{2}$ sols derived from $\mathrm{CaCl}_{2}$ [22].

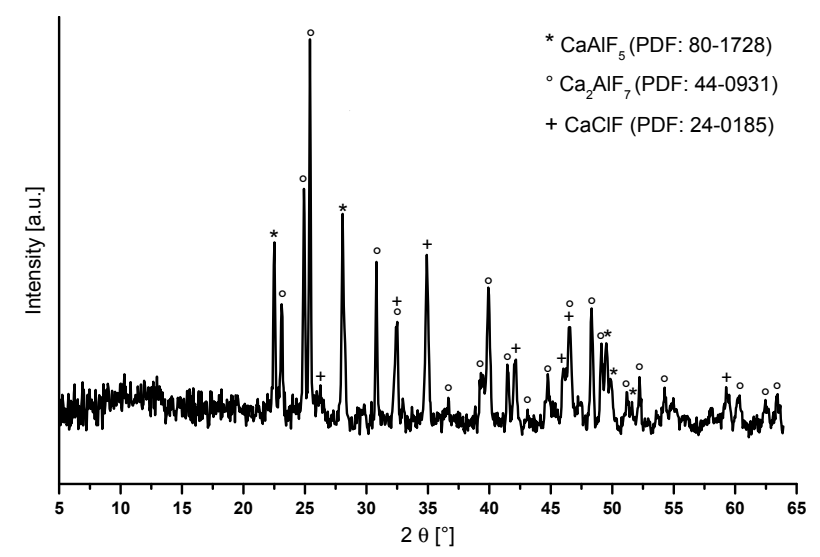

Figure 6. Powder diffractogram of annealed $\mathrm{Ca}_{2} \mathrm{AlF}_{7}$ xerogel at $700{ }^{\circ} \mathrm{C}$ for two minutes with reflections of $\mathrm{Ca}_{2} \mathrm{AlF}_{7}, \mathrm{CaAlF}_{5}$, and $\mathrm{CaClF}$.

In Figure 7, the recorded ${ }^{19} \mathrm{~F}$ MAS NMR spectra of an un-annealed and annealed xerogel and the corresponding TG/DTA heating curves confirm the formation of crystalline $\mathrm{Ca}_{2} \mathrm{AlF}_{7}$. In the NMR spectrum of the un-annealed sample, there are two very broad signals between -70 and $-110 \mathrm{ppm}$ and -120 and $-170 \mathrm{ppm}$. After calcination of the $\mathrm{Ca}_{2} \mathrm{AlF}_{7}$ xerogel at $700{ }^{\circ} \mathrm{C}$, the spectrum represents three signals at $-104.4,-146.4$, and $-154.1 \mathrm{ppm}$, which stand for $\mathrm{Ca}_{2} \mathrm{AlF}_{7}$. The signals at -84.1 , -109.5 , and -164.4 ppm correspond to $\mathrm{CaClF}, \mathrm{CaF}_{2}$, and $\mathrm{CaAlF}_{5}$, respectively.

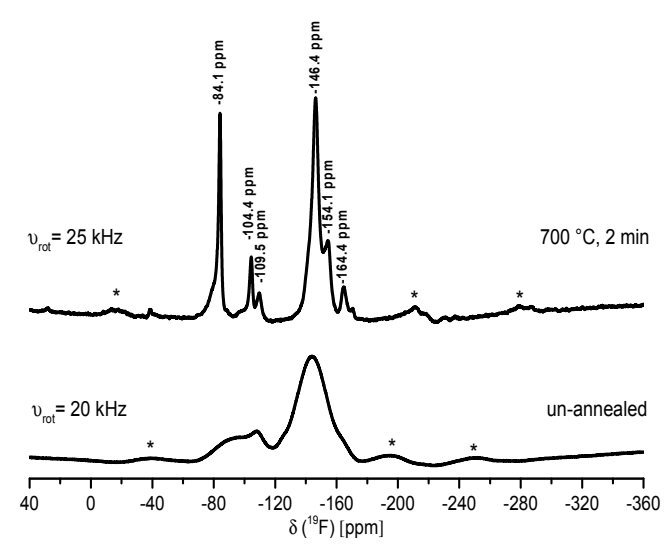

(a)

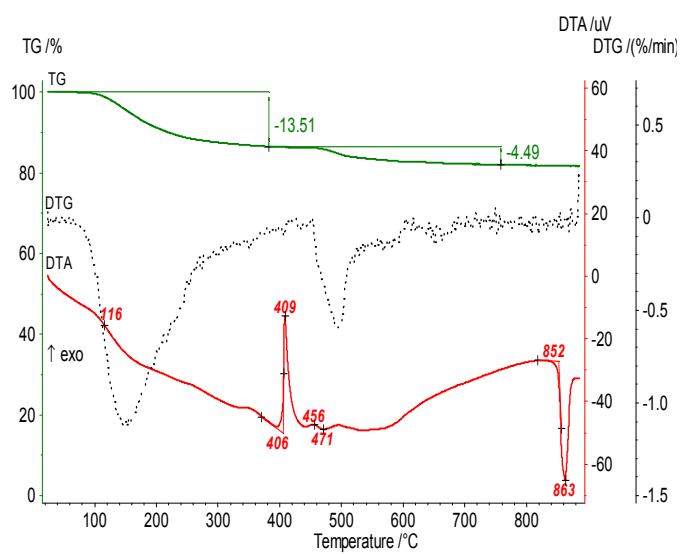

(b)

Figure 7. ${ }^{19} \mathrm{~F}$ MAS spectra of un-annealed and annealed $\mathrm{Ca}_{2} \mathrm{AlF}_{7}$ xerogel at $700{ }^{\circ} \mathrm{C}$ for two minutes (a) and TG/DTA heating curves (b). The spinning sidebands in the NMR spectrum are located under the * symbols. 
The DTA curve of the $\mathrm{Ca}_{2} \mathrm{AlF}_{7}$ xerogel shows one exothermic peak at $409{ }^{\circ} \mathrm{C}$. We assume that the crystallization of $\mathrm{CaClF}$ occurred at this temperature. The peak at $863{ }^{\circ} \mathrm{C}$ corresponds to the melting point of $\mathrm{Ca}_{2} \mathrm{AlF}_{7}$, which is lower than the melting point of the $\mathrm{CaAlF}_{5}$ xerogel at $893{ }^{\circ} \mathrm{C}$. The temperature difference of both melting points is approximately $30^{\circ} \mathrm{C}$. Thus, the melting point of $\mathrm{Ca}_{2} \mathrm{AlF}_{7}$ in the phase diagram of the $\mathrm{CaF}_{2}-\mathrm{AlF}_{3}$ binary system is $850{ }^{\circ} \mathrm{C}$. The temperature difference of both melting points from the literature and that of our investigations reveals nearly the same temperature difference of $30^{\circ} \mathrm{C}$. Hence, we are convinced that the calcium fluoroaluminates synthesized via the fluorolytic sol-gel route exhibit a similar thermal behavior to microcrystalline calcium fluoroaluminates. Therefore, we also investigated the third calcium fluoroaluminate compound $\mathrm{CaAl}_{2} \mathrm{~F}_{8}$ with a metal content of $66 \mathrm{~mol} \% \mathrm{Al}$, which is discussed in the next section.

\section{3. $\mathrm{CaAl}_{2} \mathrm{~F}_{8}$}

Although there are no reports on the synthetic calcium fluoroaluminate, $\mathrm{CaAl}_{2} \mathrm{~F}_{8}$, we prepared a sol with a nominal stoichiometry of $\mathrm{CaAl}_{2} \mathrm{~F}_{8}$. A water clear sol was obtained in this case without the addition of TMOS. In Figure 8, the ${ }^{19} \mathrm{~F}$ liquid NMR spectrum of the nominal " $\mathrm{CaAl}_{2} \mathrm{~F}_{8}$ " sol resembles the spectrum of the $\mathrm{CaAlF}_{5}$ sol (Figure 1). There are two broad and two small signals. The two broad signals at around -147 and -163 ppm correspond to $\mathrm{CaAlF}_{5}$ and the two signals at -173 and -179 ppm could probably be assigned to unreacted HF adsorbed at the particle surface. The particle size is about $10-20 \mathrm{~nm}$. But the particles have a rather non-spherical shape and tend to agglomerate to form big secondary particles of a $200 \mathrm{~nm}$ diameter.

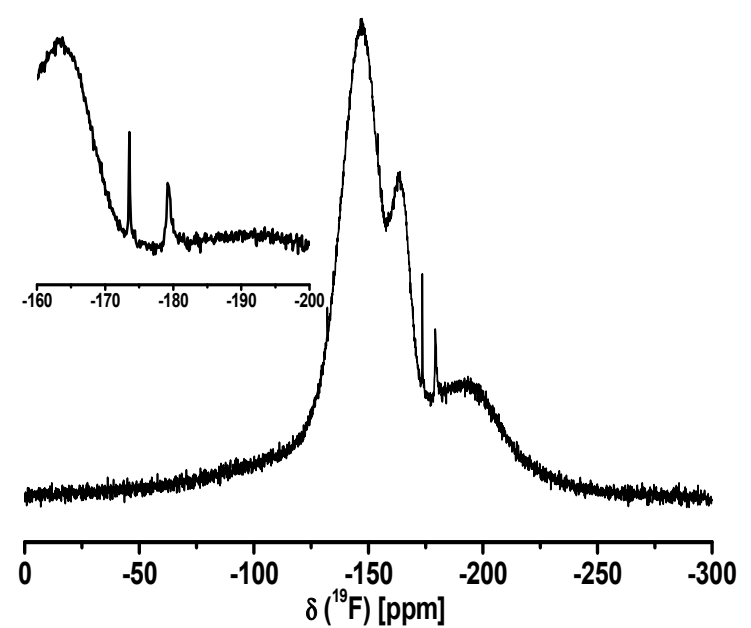

(a)

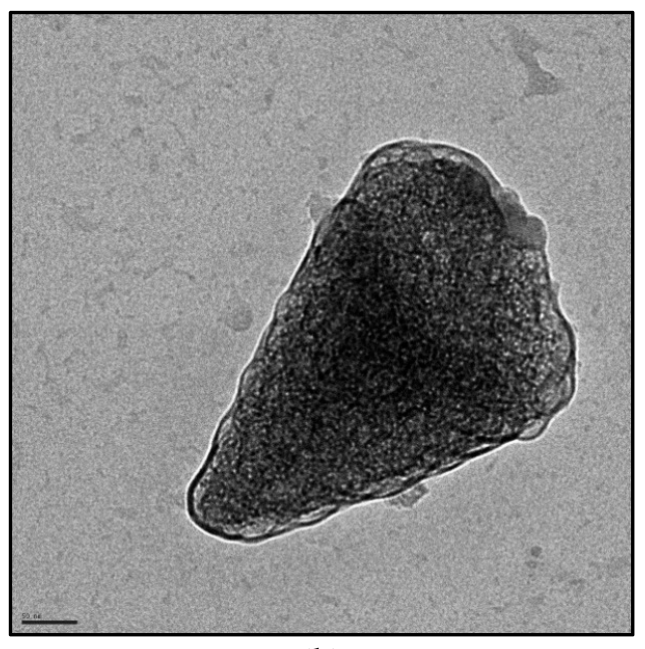

(b)

Figure 8. ${ }^{19} \mathrm{~F}$ liquid NMR spectrum (a) and TEM image (b) of the nominal " $\mathrm{CaAl}_{2} \mathrm{~F}_{8}$ " sol in EtOH (scale bar $=50 \mathrm{~nm})$.

The annealed " $\mathrm{CaAl}_{2} \mathrm{~F}_{8}$ " xerogel was further investigated by powder X-ray diffraction. Figure 9 shows the recorded diffractogram of the " $\mathrm{CaAl}_{2} \mathrm{~F}_{8}$ " xerogel. There are reflections of $\mathrm{CaAlF} 5 \mathrm{and} \mathrm{AlF}_{3}$, and a reflection that cannot be assigned to any known phase. It is obvious that no " $\mathrm{CaAl}_{2} \mathrm{~F}_{8}$ " phase has been formed under these conditions. This is also in agreement with the $\mathrm{CaF}_{2}-\mathrm{AlF}_{3}$ binary phase diagram. At a ratio of $66 \mathrm{~mol} \% \mathrm{Al}$ and $33 \% \mathrm{~mol} \% \mathrm{Ca}$ at $700{ }^{\circ} \mathrm{C}$, the formation of crystalline $\alpha-\mathrm{CaAlF}_{5}$ and $\beta-\mathrm{AlF}_{3}$ is expected.

In line with this, the ${ }^{19} \mathrm{~F}$ MAS spectrum of the un-annealed sample reveals one broad signal between -125 and $-175 \mathrm{ppm}$, and the " $\mathrm{CaAl}_{2} \mathrm{~F}_{8}$ " xerogel after annealing at $700{ }^{\circ} \mathrm{C}$ for two minutes in a closed crucible exhibits five signals in the spectrum. Three signals at $-145.8,-154.4$, and $-164.7 \mathrm{ppm}$ stand for $\mathrm{CaAlF}_{5}$. The signal at $-141.9 \mathrm{ppm}$ can probably be assigned to $\beta-\mathrm{CaAlF}_{5}$, which has four different fluorine sites. The last signal at $-173.5 \mathrm{ppm}$ can be assigned to $\mathrm{AlF}_{3}$ (Figure 10a). The DTA heating curve of the " $\mathrm{CaAl}_{2} \mathrm{~F}_{8}$ " xerogel shows two exothermic peaks at 347 and $427{ }^{\circ} \mathrm{C}$, which stand 
for the crystallization and polymorphic inversion of $\alpha-\mathrm{AlF}_{3}$. The peak at $904{ }^{\circ} \mathrm{C}$ indicates the melting of $\mathrm{CaAlF}_{5}$, which is consistent with the phase diagram of the binary $\mathrm{CaF}_{2}-\mathrm{AlF}_{3}$ system. The " $\mathrm{CaAl}_{2} \mathrm{~F}_{8}$ " xerogel in fact consists of $\mathrm{CaAlF}_{5}$ and $\mathrm{AlF}_{3}$ (Figure 10b). This means that no formation of a " $\mathrm{CaAl}_{2} \mathrm{~F}_{8}$ " phase was detected under these conditions.

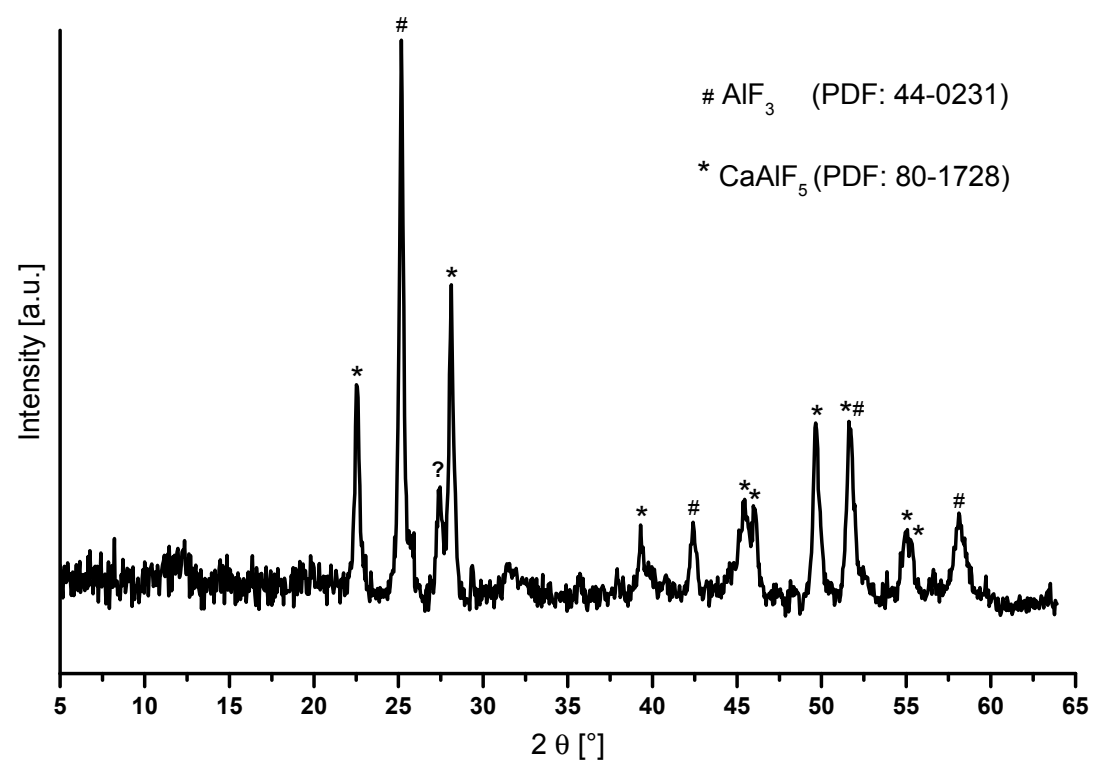

Figure 9. Powder diffractogram of the annealed nominal " $\mathrm{CaAl} 2 \mathrm{~F}_{8}$ " xerogel at $700{ }^{\circ} \mathrm{C}$ for two minutes with reflections of $\mathrm{CaAlF}_{5}$ and $\mathrm{AlF}_{3}$.

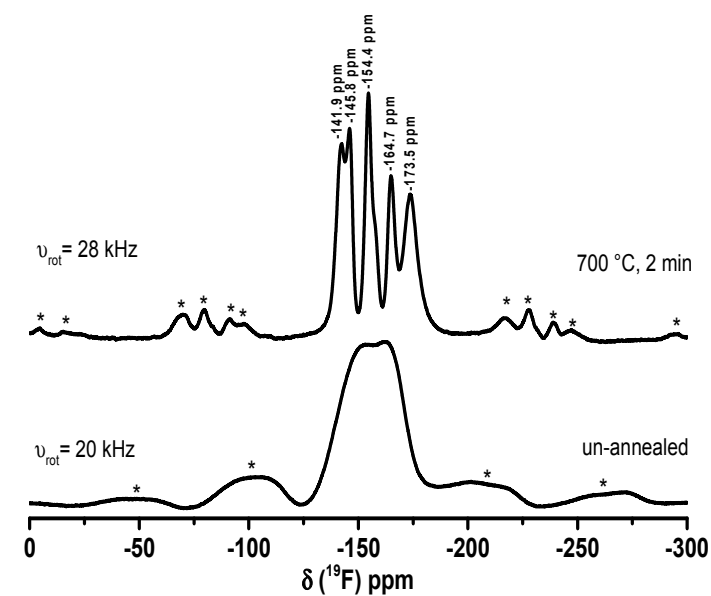

(a)

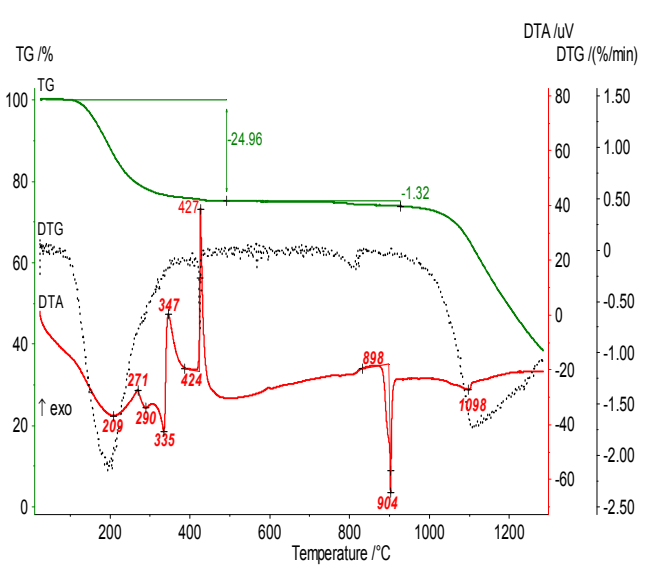

(b)

Figure 10. ${ }^{19} \mathrm{~F}$ MAS spectra of un-annealed and annealed $\mathrm{CaAl}_{2} \mathrm{~F}_{8}$ xerogel at $700{ }^{\circ} \mathrm{C}$ for two minutes (a) and TG/DTA heating curves (b). The spinning sidebands in the NMR spectrum are located under the * symbols.

\section{4. $\operatorname{LiMgAlF}_{6}$}

The possibility to achieve quaternary metal fluorides by fluorolytic sol-gel synthesis was also tested. We achieved transparent and stable $\mathrm{LiMgAlF}_{6}$ sols in EtOH. The ${ }^{19} \mathrm{~F}$ liquid NMR spectrum of the $\mathrm{LiMgAlF}_{6}$ sol is shown in Figure 11a and reveals two broad signals at -164 and $-182 \mathrm{ppm}$. The signal at $-164 \mathrm{ppm}$ is probably a fluorinated aluminum alkoxide species. The signal at $-182 \mathrm{ppm}$ with the corresponding shoulder can either be ascribed to a high amount of unreacted HF adsorbed at the particle surface or incompletely fluorinated $\mathrm{MgCl}_{2}$. The small broad signal ( $-135 \mathrm{ppm}$ ) and the small signal $(-153 \mathrm{ppm})$ are due to the reaction of the unreacted HF with the glass flask. Hence, the signals 
at $-135 \mathrm{ppm}$ and $-153 \mathrm{ppm}$ are $\mathrm{SiF}_{x}$ and $\mathrm{BF}_{4}{ }^{-}$species, respectively. The TEM image in Figure $11 \mathrm{~b}$ shows nearly spherical shape particles with a size of about $10 \mathrm{~nm}$.

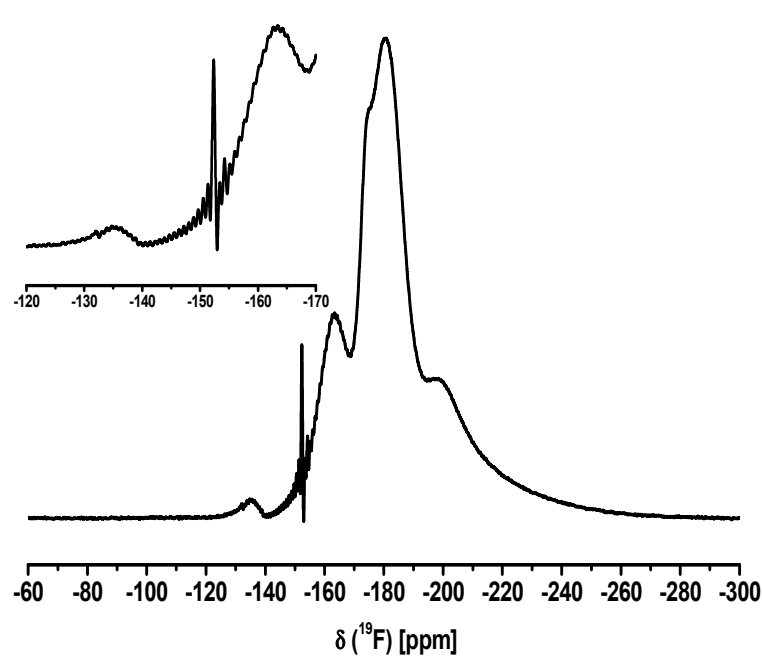

(a)

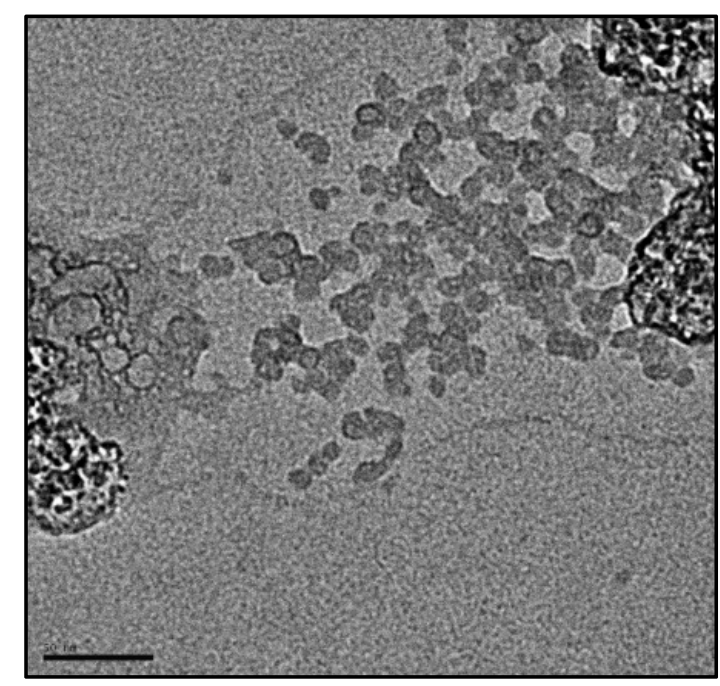

(b)

Figure 11. ${ }^{19} \mathrm{~F}$ liquid NMR spectrum $(\mathbf{a})$ and TEM image $(\mathbf{b})$ of $\mathrm{LiMgAlF}_{6}$ sol in $\mathrm{EtOH}$ (scale bar $=50 \mathrm{~nm}$ ).

The annealed $\mathrm{LiMgAlF}_{6}$ xerogel was measured by powder X-ray diffraction. As can be seen in Figure 12, there are reflections of the $\mathrm{LiMgAlF}_{6}$ phase and $\mathrm{MgF}_{2}$ in the diffractogram. Surprisingly, the use of a closed crucible is not necessary. It can be assumed that the formation of $\mathrm{AlF}_{3}$ is thermodynamically not favored in this reaction system, unlike the formation of $\mathrm{MgF}_{2}$.

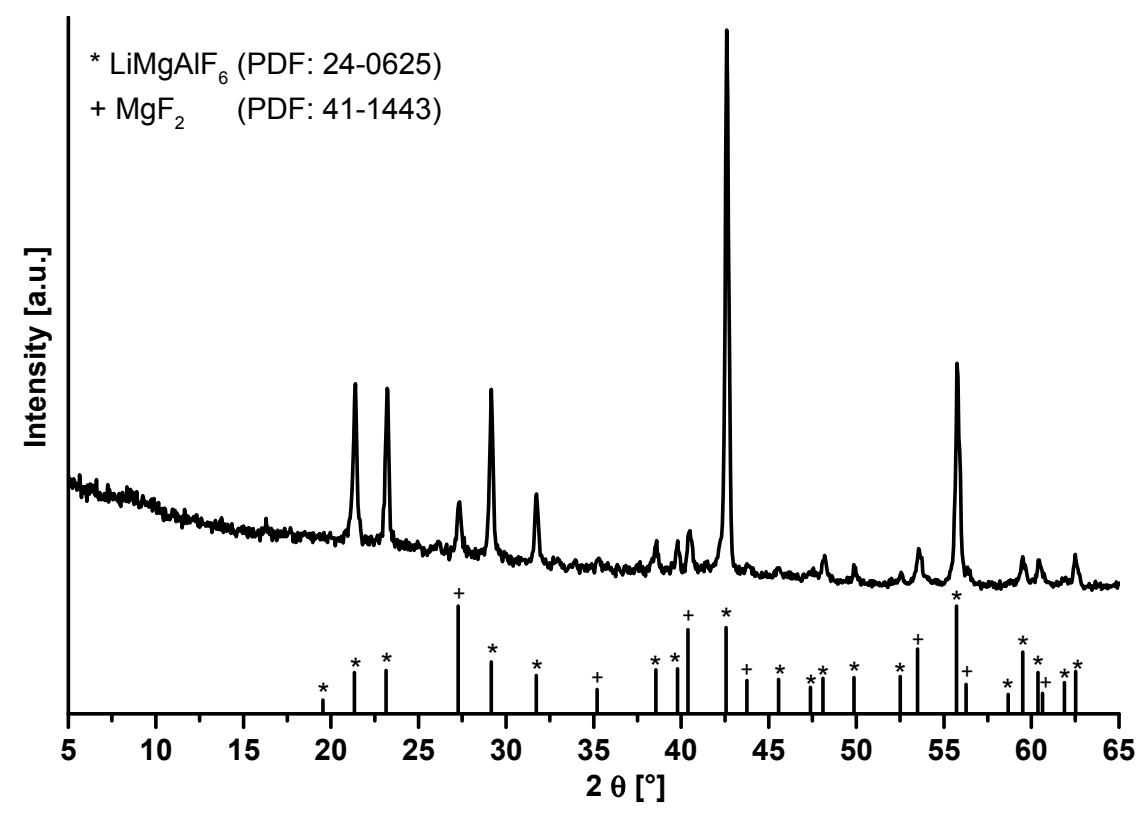

Figure 12. Comparison of powder $\mathrm{X}$-ray patterns of $\mathrm{LiMgAlF}_{6}$ xerogel in an open crucible at $500{ }^{\circ} \mathrm{C}$ for a one hour calcination time in a non-preheated oven with crystalline $\mathrm{LiMgAlF}_{6}$ phase (PDF: 24-0625) and $\mathrm{MgF}_{2}$ phase (PDF: 41-1443).

The DTA heating curve of the $\mathrm{LiMgAlF}_{6}$ xerogel (Figure 13) shows an exothermic peak at $383^{\circ} \mathrm{C}$ which stands for crystallization and the peak at $768^{\circ} \mathrm{C}$ compares very well to the melting point of $\mathrm{LiMgAlF}_{6}$. 


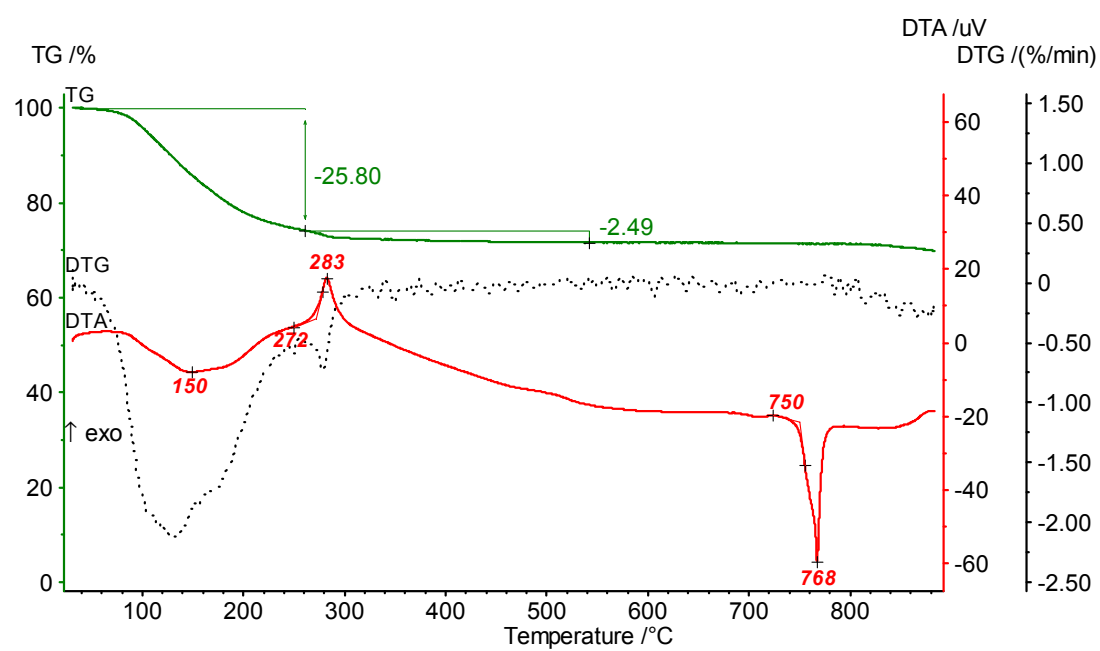

Figure 13. TG/DTA heating curves of $\mathrm{LiMgAlF}_{6}$.

\section{Materials and Methods}

\subsection{Synthesis of Complex Metal Fluoride Sols}

All chemicals for the synthesis of ternary and quaternary metal fluorides are commercially available and need no drying or further processing. The 19.05 M HF-solution was prepared by dissolving anhydrous HF in ethanol. The molar concentration of the sols refers to the total metal concentration of $0.4 \mathrm{M}$ in the corresponding complex metal fluoride compound.

The stoichiometric fluoride compounds $\mathrm{CaAl}_{2} \mathrm{~F}_{8}, \mathrm{CaAlF}_{5}, \mathrm{LiMgF}_{3}$, and $\mathrm{LiMgAlF}_{6}$ were prepared as follows: Anhydrous $\mathrm{CaCl}_{2}$ ( $\geq 97 \%$, Sigma-Aldrich), $\mathrm{MgCl}_{2}$ ( $\geq 98 \%$, Sigma-Aldrich, Schnelldorf, Germany), and LiOMe (95\%, Strem Chemicals, Kehl, Germany), respectively, were dissolved in $50 \mathrm{~mL}$ ethanol (99.8\%, Roth, Karlsruhe, Germany). Afterwards, $\mathrm{Al}\left(\mathrm{O}^{i} \mathrm{Pr}\right)_{3}$ ( $\geq 98 \%$, Sigma-Aldrich) was suspended into the solution. Under vigorous stirring at ambient conditions, the required amount of HF-solution was added dropwise to the suspension. In case of $\mathrm{Ca}_{2} \mathrm{AlF}_{7}$, the addition of $5 \mathrm{~mol} \%$ tetramethyl orthosilicate (TMOS) after fluorination turns an opaque sol into a transparent $\mathrm{Ca}_{2} \mathrm{AlF}_{7}$ sol. Apparently, the presence of metal chloride in the sol and the addition of TMOS after fluorination ensures a higher electrostatic repulsion of the nanoparticles than without the addition of TMOS which increases the particle stabilization. The sols were dried under vacuum at $80^{\circ} \mathrm{C}$ to obtain the corresponding xerogels.

\subsection{Analytical Measurements}

The ${ }^{19} \mathrm{~F}$ NMR spectra of the sols were obtained by using a Bruker AVANCE II (liquid state NMR spectrometer with a Larmor frequency of $282.4 \mathrm{MHz}$ ). The ${ }^{19} \mathrm{~F}$ isotropic chemical shifts are given with respect to the $\mathrm{CFCl}_{3}$ standard.

Transmission Electron Microscope (TEM) analysis was carried out using a Philips CM200 LaB 6 microscope operating at $200 \mathrm{kV}$. A few drops of the solution $(0.1 \mathrm{mM})$ containing the nanoparticles were deposited on a carbon-coated copper grid and were left to dry prior to the inspection.

Thermal analysis experiments of the complex metal fluorides were performed on a STA $409{ }^{\circ} \mathrm{C}$ (Netzsch Gerätebau GmbH, Selb, Germany). A DTA-TG sample-holder system (Pt/PtRh10 thermocouple) was used. The thermoanalytical curves (TG, DTA and DTG) were recorded under air atmosphere with a constant heating rate of $10 \mathrm{~K} / \mathrm{min}$.

The xerogels were characterized by an X-ray powder diffractometer from Seifert (XRD 3003 TT) and by ${ }^{19} \mathrm{~F}$ solid state NMR spectroscopy. Phases were identified by a comparison with the ICDD (international center for diffraction data) powder diffraction file [41]. The ${ }^{19} \mathrm{~F}$ MAS NMR spectra were recorded with a Bruker AVANCE 400 (solid state spectrometer, Larmor frequency of $376.4 \mathrm{MHz}$ ) with a $\pi / 2$ pulse duration of $3.6 \mu \mathrm{s}$ in a $2.5 \mathrm{~mm}$ Bruker probe, a recycle delay of $5 \mathrm{~s}$, and accumulation 
number of 64 . The experiments were performed with a rotation frequency of $20 \mathrm{kHz}$. The ${ }^{19} \mathrm{~F}$ isotropic chemical shifts are given with respect to the $\mathrm{CFCl}_{3}$ standard. The xerogels were calcined in a preheated vented air-oven (Barnstead thermolyne F47900, Dubuque, IA, USA) at $500{ }^{\circ} \mathrm{C}$ and $700{ }^{\circ} \mathrm{C}$, respectively. The dwell time was 2 and $60 \mathrm{~min}$, respectively. After the dwell time, the sample was quickly taken out of the oven and cooled down to room temperature.

\section{Conclusions}

The fluorolytic sol-gel synthesis, so far mainly used for the synthesis of binary or ternary metal fluorides, has been successfully applied for the synthesis of nanoscaled, homodispersed complex metal fluoride sols $\left(\mathrm{CaAlF}_{5}, \mathrm{Ca}_{2} \mathrm{AlF}_{7}, \mathrm{LiMgAlF}_{6}\right)$ using $\mathrm{CaCl}_{2}, \mathrm{MgCl}_{2}$, $\mathrm{LiOMe}$, and $\mathrm{Al}\left(\mathrm{O}^{i} \mathrm{Pr}\right)_{3}$ as metal precursors, which were reacted with anhydrous HF in ethanol. All complex metal fluoride sols showed long-time stability and transparency even after months. These complex metal fluorides recently gained an enormous amount of interest as hosts for fluorescent materials [1-7] due to the suitable sizes of the ionic radii of alkaline earth cations. In addition, they exhibit high ionic strength, hardness, good isolation behavior, and are stable over a wide temperature range. Hence, based on the new synthesis approach reported here, an alternative and very effective synthesis approach for such fluorescent materials is provided. Even bulk ceramics are accessible starting from such nano powdered complex metal fluorides. Based on XRD and MAS-NMR-investigations, the formation of these complex metal fluorides already at room temperature was unambiguously proven. Thus, these results show that the fluorolytic sol gel synthesis is not limited to binary metal fluorides, but can also be successfully adapted for even more complex metal fluoride systems.

Thus, a new synthesis path has been explored for a variety of new, optically very interesting complex metal fluoride-based materials.

Supplementary Materials: The following are available online at www.mdpi.com/2079-4991/7/11/362/s1, Figure S1: Photograph of a typical transparent $\mathrm{LiMgF}_{3}$ sol, Figure S2: ${ }^{19} \mathrm{~F}$ liquid NMR spectrum of $\mathrm{LiMgF}_{3}$ sol, Figure S3: TEM image of $\mathrm{LiMgF}_{3}$ sol, Figure S4: X-Ray powder diffractogram of un-annealed $\mathrm{LiMgF}_{3}$ xerogel, Figure S5: Comparison of X-ray powder patterns of annealed $\mathrm{LiMgF}_{3}$ xerogel at $700{ }^{\circ} \mathrm{C}(\mathrm{a}), 850{ }^{\circ} \mathrm{C}$ (b) for 2 min and crystalline $\mathrm{MgF}_{2}(\mathrm{PDF}$ : 41-1443) and LiF (PDF: 04-0857), Figure S6: TG/DTA heating curves of $\mathrm{LiMgF}_{3}$ xerogel.

Acknowledgments: This work was financed by the graduate school GRK 1582 "Fluorine as a key element" by the Deutsche Forschungsgemeinschaft (DFG). We thank Michael Feist for DTA/TG- and Stefan Mahn for TEM-measurements.

Author Contributions: Alexander Rehmer performed the syntheses and wrote the paper. Kerstin Scheurell and Gudrun Scholz analyzed, evaluated and discussed the data. Erhard Kemnitz was responsible for coordinating the experiments and correcting the manuscript.

Conflicts of Interest: The authors declare no conflict of interest.

\section{References}

1. Du, M.H. Chemical stability and Ce doping of $\mathrm{LiMgAlF}_{6}$ neutron scintillator. J. Alloys Compd. 2015, 622, 925-928. [CrossRef]

2. Belsare, P.D.; Joshi, C.P.; Moharil, S.V.; Omanwarc, S.K.; Muthald, P.L.; Dhopted, S.M. Preparation and characterization of $\mathrm{LiAEAlF}_{6} \mathrm{Eu}(\mathrm{AE}=\mathrm{Mg}, \mathrm{Ca}$, Sr or Ba) phosphors. J. Lumin. 2009, 129, 135-139. [CrossRef]

3. Samtleben, T.A.; Hulliger, E. $\mathrm{LiCaAlF}_{6}$ and $\mathrm{LiSrAlF}_{6}$ : Tunable solid state laser host materials. Opt. Lasers Eng. 2005, 43, 251-262. [CrossRef]

4. Van der Kolk, E.; Dorenbos, P.; van Eijk, C.W.E. Luminescence excitation study of the higher energy states of $\mathrm{Pr}^{3+}$ and $\mathrm{Mn}^{2+}$ in $\mathrm{SrAlF}_{5}, \mathrm{CaAlF}_{5}$, and $\mathrm{NaMgF}_{3}$. J. Appl. Phys. 2004, 95, 7867-7872. [CrossRef]

5. Gektin, A.; Shiran, N.; Neicheva, S.; Gavrilyuk, V.; Bensalah, A.; Fukuda, T.; Shimamura, K. LiCaAlF 6 :Ce crystal: A new scintillator. Nucl. Instrum. Methods Phys. Res. Sect. A 2002, 486, 274-277. [CrossRef]

6. Tao, F.; Hong, G.Y.; Zhu, S.F.; You, H.; Zhou, X.; Zhao, B. Synthesis and spectroscopic characteristics of $\mathrm{LiMgAlF}_{6}: \mathrm{RE}^{3+}(\mathrm{RE}=\mathrm{Eu}, \mathrm{Tm}, \mathrm{Gd})$. Phys. Status Solidi A-Appl. Res. 1998, 165, 303-308. [CrossRef]

7. Tao, F.; Zhou, X.J.; Zhu, S.F.; Zhao, B.; Hong, G.; You, H. Synthesis and luminescence characteristics of $\mathrm{LiMgAlF}_{6}: \mathrm{Ln}^{3+}(\mathrm{Ln}=\mathrm{Ce}, \mathrm{Eu}, \mathrm{Tb})$. Cryst. Res. Technol. 1997, 32, 849-855. [CrossRef] 
8. Bessoi, M.; Soren, S.; Parhi, P. Rapid microwave mediated hydrothermal synthesis of complex ternary fluorides. Ceram. Int. 2016, 42, 3697-3700. [CrossRef]

9. Zakalyukin, R.M.; Fedorov, P.P. Classification of fluoroaluminate glasses. Inorg. Mater. 2003, 39, 640-644. [CrossRef]

10. Ehrt, D.; Vogel, W. Fluoroaluminate glass. J. Fluorine Chem. 1985, 29, 54. [CrossRef]

11. Krauß, M.; Ehrt, D.; Heide, K.; Vogel, W. Phasenanalytische Untersuchungen im System $\mathrm{CaF}_{2}-\mathrm{AlF}_{3}$. Z. Chem. 1984, 24, 247-250. [CrossRef]

12. Ehrt, D.; Krauß, M.; Erdmann, C.; Vogel, W. Fluoroaluminatgläser; $\left.{ }^{1}\right)$ Systeme $\mathrm{CaF}_{2}-\mathrm{AlF}_{3}$ und $\mathrm{MgF}_{2}-\mathrm{CaF}_{2}-\mathrm{AlF}_{3}$. Z. Chem. 1982, 22, 315-316. [CrossRef]

13. Zhang, X.; Quan, Z.; Yang, J.; Yang, P.; Lian, H.; Lin, J. Solvothermal synthesis of well-dispersed $\mathrm{NaMgF}_{3}$ nanocrystals and their optical properties. J. Colloid Interface Sci. 2009, 329, 103-106. [CrossRef] [PubMed]

14. Kemnitz, E.; Gross, U.; Rudiger, S.; Shekar, S.H. Amorphous Metal Fluorides with Extraordinary High Surface Areas. Angew. Chem. Int. Ed. 2003, 42, 4251-4254. [CrossRef] [PubMed]

15. Gross, U.; Ruediger, S.; Kemnitz, E. Alkaline earth fluorides and their complexes: A sol-gel fluorination study. Solid State Sci. 2007, 9, 838-842. [CrossRef]

16. Ahrens, M.; Scholz, G.; Feist, M.; Kemnitz, E. Application of an alkoxide sol-gel route for the preparation of complex fluorides of the $\mathrm{MAlF}_{4}(\mathrm{M}=\mathrm{K}, \mathrm{Cs}), \mathrm{M}_{3} \mathrm{AlF}_{6}(\mathrm{M}=\mathrm{Li}, \mathrm{Na}, \mathrm{K})$, and $\mathrm{Na}_{5} \mathrm{Al}_{3} \mathrm{~F}_{14}$ type. Solid State Sci. 2006, 8, 798-806. [CrossRef]

17. Kohl, J.; Wiedemann, D.; Nakhal, S.; Bottke, P.; Ferro, N.; Bredow, T.; Kemnitz, E.; Wilkening, M.; Heitjanse, P.; Lerch, M. Synthesis of ternary transition metal fluorides $\mathrm{Li}_{3} \mathrm{MF}_{6}$ via a sol-gel route as candidates for cathode materials in lithium-ion batteries. J. Mater. Chem. 2012, 22, 15819-15827. [CrossRef]

18. Krahl, T.; Scheurell, K.; Kemnitz, E. Novel aspects in the chemistry of the non-aqueous fluorolytic sol-gel synthesis of nanoscaled homodisperse $\mathrm{MgF}_{2}$ sols for antireflective coatings. J. Mater. Chem. C 2016, 4, 1454-1466. [CrossRef]

19. Ruediger, S.K.; Gross, U.; Feist, M.; Prescott, H.A.; Shekar, S.C.; Troyanova, S.I.; Kemnitz, E. Non-aqueous synthesis of high surface area aluminium fluoride-A mechanistic investigation. J. Mater. Chem. 2005, 15, 588-597. [CrossRef]

20. Scheurell, K.; Kemnitz, E.; Garcia-Juan, P.; Eicher, J.; Lintner, B.; Hegmann, J.; Jahn, R.; Hofmann, T.; Löbmann, P. Porous $\mathrm{MgF}_{2}$ antireflective $\lambda / 4$ films prepared by sol-gel processing: Comparison of synthesis approaches. J. Sol-Gel Sci. Technol. 2015, 76, 82-89. [CrossRef]

21. Noack, J.; Scheurell, K.; Kemnitz, E.; Garcia-Juan, P.; Rau, H.; Lacroix, M.; Eicher, J.; Lintner, B.; Sontheimer, T.; Hofmann, T.; et al. $\mathrm{MgF}_{2}$ antireflective coatings by sol-gel processing: Film preparation and thermal densification. J. Mater. Chem. 2012, 22, 18535-18541. [CrossRef]

22. Rehmer, A.; Scheurell, K.; Kemnitz, E. Formation of nanoscopic $\mathrm{CaF}_{2}$ via a fluorolytic sol-gel process for antireflective coatings. J. Mater. Chem. C 2015, 3, 1716-1723. [CrossRef]

23. Kemnitz, E.; Noack, J. The non-aqueous fluorolytic sol-gel synthesis of nanoscaled metal fluorides. Dalton Trans. 2015, 44, 19411-19431. [CrossRef] [PubMed]

24. Carta, D.; Pickup, D.M.; Knowles, J.C.; Smith, M.E.; Newport, R.J. Sol-gel synthesis of the $\mathrm{P}_{2} \mathrm{O}_{5}-\mathrm{CaO}_{-} \mathrm{Na}_{2} \mathrm{O}-\mathrm{SiO} 2$ system as a novel bioresorbable glass. J. Mater. Chem. 2005, 15, 2134-2140. [CrossRef]

25. Scholz, G.; Stosiek, C.; Noack, J.; Kemnitz, E. Local fluorine environments in nanoscopic magnesium hydr(oxide) fluorides studied by ${ }^{19}$ F MAS NMR. J. Fluorine Chem. 2011, 132, 1079-1085. [CrossRef]

26. Craig, D.F.; Brown, J.J. Phase equilibria in system $\mathrm{CaF}_{2}-\mathrm{AlF}_{3}$. J. Am. Ceram. Soc. 1977, 60, 396-398. [CrossRef]

27. Millet, J.P.; Rolin, M. Study of the median part of the phase $\mathrm{CaF}_{2}-\mathrm{AlF}_{3}$ - Confirmation of a stability field for the compound $\mathrm{Ca}_{2} \mathrm{AlF}_{7}$. Rev. Int. Hautes Temp. Refract. 1981, 18, 287-292.

28. Fedotiev, P.P.; Ilyinskii, V. Fusibility of the ternary system NaF-CaF $2-\mathrm{AIF}_{3}$. Z. Anorg. Allgem. Chem. 1923, 129, 93-107.

29. Holm, J.L. Phase equilibria in system $\mathrm{CaF}_{2}-\mathrm{AlF}_{3}$. Acta Chem. Scand. 1965, 19, 1512-1514. [CrossRef]

30. Hemon, A.; Courbion, G. Refinement of the room temperature structure of $\alpha-\mathrm{CaAlF}_{5}$. Acta Crystallogr. Sect. C-Cryst. Struct. Commun. 1991, 47, 1302-1303. [CrossRef]

31. Body, M.; Silly, G.; Legein, C.; Buzaréa, J.-Y.; Calvayraca, F.; Blahad, P. Structural investigations of beta-CaAlF 5 by coupling powder XRD, NMR, EPR and spectroscopic parameter calculations. J. Solid State Chem. 2005, 178, 3655-3661. [CrossRef]

32. Body, M.; Silly, G.; Legein, C.; Buzare, J.Y. Correlation between ${ }^{19}$ F environment and isotropic chemical shift in barium and calcium fluoroaluminates. Inorg. Chem. 2004, 43, 2474-2485. [CrossRef] [PubMed] 
33. Domesle, R.; Hoppe, R. The crystal structure of $\mathrm{Ca}_{2} \mathrm{AlF}_{7}$. Z. Kristall. 1980, 153, 317-328.

34. Kiczenski, T.J.; Du, L.-S.; Stebbins, J.F. F-19 NMR study of the ordering of high field strength cations at fluoride sites in silicate and aluminosilicate glasses. J. Non-Cryst. Solids 2004, 337, 142-149. [CrossRef]

35. Kiczenski, T.J.; Stebbins, J.F. Fluorine sites in calcium and barium oxyfluorides: F-19 NMR on crystalline model compounds and glasses. J. Non-Cryst. Solids 2002, 306, 160-168. [CrossRef]

36. Balic-Zunic, T.; Garavelli, A.; Mitolo, D.; Acquafredda, P.; Leonardsen, E. Jakobssonite, CaAlF 5 , a new mineral from fumaroles at the Eldfell and Hekla volcanoes, Iceland. Mineral. Mag. 2012, 76, 751-760. [CrossRef]

37. Kampf, A.R.; Colombo, F.; del Tanago, J.G. Carlhintzeite, $\mathrm{Ca}_{2} \mathrm{AlF}_{7}$ center $\operatorname{dot} \mathrm{H}_{2} \mathrm{O}$, from the Gigante granitic pegmatite, Cordoba province, Argentina: Description and crystal structure. Mineral. Mag. 2010, 74, 623-632. [CrossRef]

38. Karg, M.; Scholz, G.; Koenig, R.; Kemnitz, E. Mechanistic insight into formation and changes of nanoparticles in $\mathrm{MgF}_{2}$ sols evidenced by liquid and solid state NMR. Dalton Trans. 2012, 41, 2360-2366. [CrossRef] [PubMed]

39. Holm, J.L.; Holm, B.J. Phase relations and thermodynamic properties in the ternary reciprocal system LiF-NaF-Na $\mathrm{AlF}_{6}-\mathrm{Li}_{3} \mathrm{AlF}_{6}$. Thermochim. Acta 1973, 6, 375-398. [CrossRef]

40. Voronkov, M.G.; Boyarkina, E.V.; Gebel, I.A.; Albanov, A.I.; Basenko, S.V. Cleavage of the C-Si bond in trifluoro(phenyl)silane with aliphatic alcohols. Russ. J. Gen. Chem. 2005, 75, 1927-1929. [CrossRef]

41. JCPDS-ICDD, International Centre for Diffraction Data: PDF-2 Database; PCPDFWIN Version 2.2; ICDD: Newtown Square, PA, USA, 2001.

(C) 2017 by the authors. Licensee MDPI, Basel, Switzerland. This article is an open access article distributed under the terms and conditions of the Creative Commons Attribution (CC BY) license (http:// creativecommons.org/licenses/by/4.0/). 